\title{
Effect of Acupressure on Nausea and Vomiting during Pregnancy
}

\author{
MAHA M. MADY, Ph.D. ${ }^{\mathbf{1}}$; SAFAA G. ALY, D.N.Sc. ${ }^{\mathbf{2 , 3}}$; INASS K. ALY, D.N.Sc. ${ }^{\mathbf{2}}$ and \\ AYAT M.A. EL-ABD, M.Sc. ${ }^{4}$ \\ The Department of Physical Therapy for Women's Health, Teaching Hospital, Shebin El-Kom, Egypt \\ The Department of Maternal \& Newborn Health Nursing, Faculty of Nursing, Menoufia University, \\ Shebin El-Kom, Egypt ${ }^{2}$, Princess Norah Bint Abdulrahman University, Riyadh, Saudi Arabia ${ }^{3}$ and \\ Al-Shohadaa General Hospital, Menoufia, Egypt ${ }^{4}$
}

\begin{abstract}
Background: Acupressure is a part of traditional Chinese medicine to stimulate energy channels below the skin surface, it reduces stress and restores health.

Aim of Study: To assess the effect of acupressure on nausea and vomiting during pregnancy.

Material and Methods: 100 pregnant women with gestational age less than 15 weeks were included in a 7 consecutive day's study. They were randomly divided into two groups: A study and control group. The study group received Acupressure on the pericardium 6 points $(\mathrm{P} 6)$ bilaterally for about 60 minutes per day for 7 consecutive days. While the control group received only $\mathrm{P} 6$ touch with the same steps and period. Gathering data and Rhodes index scale were completed for both groups.

Results: In the study group, the severity and frequency of nausea and vomiting reduced significantly after starting the treatment compared to the control group.

Conclusions: $\mathrm{P} 6$ acupressure is effective in reducing the severity and frequency of nausea and vomiting during pregnancy.
\end{abstract}

Key Words: Acupressure - Nausea - Vomiting - Pregnancy $-P 6$.

\section{Introduction}

NAUSEA and vomiting are common hard symptoms experienced by pregnant women in early pregnancy between the fourth and seventh week of pregnancy in 80 percent of pregnant women and resolves by the 20 th week of gestation. These symptoms can have a reflective impact on women's general sense of well-being and day-today lives [1-3].

\footnotetext{
Correspondence to: Dr. Maha Mohamed Mady, E-Mail: mahamady12@yahoo.com nour508@hotmail.com
}

The condition has been shown to be more common in urban women than in rural women, with increased risk in housewives and decreased risk in "white collar" women, and in women over 35 years of age with a history of infertility [4].

The most severe manifestations of Nausea and Vomiting of Pregnancy (NVP) result in Hyperemesis Gravidarum (HG). Although there is no standard definition of $\mathrm{HG}$, the most diagnostic criteria include persistent vomiting before 9 weeks after the LMP, weight loss $>5 \%$ of initial body weight, electrolyte imbalance (Hypokalemia), and dehydration and/or ketonuria [5]

The most common risk factors of hyperemesis gravidarum were gastrointestinal diseases, urinary tract infection, and multiple pregnancies. The overall hospital rate of hyperemesis gravidarum at some Woman's Health Centers in Egypt may reach $4.5 \%$ which was considered a high prevalence in relation to the universal prevalence of hyperemesis gravidarum [6].

Nausea and vomiting in pregnancy caused adverse psychosocial effects, including concerns about economics and employment, depression, anxiety, fear about future pregnancies and relationships with family and partners [7].

Nausea and vomit of physiological condition with multiple consequences, together with the threat of miscarriage, vertebrate and deathrate throughout, congenital disorder, system abnormalities, low birth weight baby, premature delivery is associated with malnutrition and weight loss [8].

The management of nausea and regurgitation of gestation depends on the severity of the symptoms. Treatment measures range from dietary 
changes to more aggressive approaches involving antiemetic medications, hospitalization, or even total parenteral nutrition in addition to vitamins, behavioral therapy, Acupressure, Acupuncture, and Ginger $[\mathbf{9 , 1 0 ]}$

Acupressure is a modality of traditional Chinese medicine in which pressure is applied to various points on the body to relieve illness or induce relaxation [11].

\section{Material and Methods}

The study was conducted in the Maternal and Child Health Center of Kafr-Ashma in the period from May 2016 and completed by November 2016.

100 pregnant women were complaining from nausea and vomiting, were divided randomly by a simple method according to days of the week as; patients came at (Saturdays, Mondays, and Wednesdays) were rolled in (Group A: Study group). While, patients came at (Sundays, Tuesdays, and Thursdays) were rolled in (Group B: Control group). The study group included 50 women received $\mathrm{P} 6$ Acupressure. While control group included 50 women received only touch at the same point.

Inclusion criteria include primipara women aged from 20 to 35 years, suffered from mild to moderate nausea and/or vomiting in early pregnancy before 14 weeks of gestation, had no medical problems, no use of any methods for treatment of nausea and vomiting in the past 3 weeks, no pregnancy complications and no damage, bruises or irritation at the $\mathrm{p}_{6}$ Acupoint.

\section{Material:}

- A constructed interview questionnaire included socio-demographic characteristics of pregnant women, medical and family history, besides data regarding the current pregnancy, in addition to data about nausea and vomiting during pregnancy.

- Rhodes index assessment tool: To evaluate the severity and frequency of nausea and vomiting. It included separately scores, as categorical variables, the number of vomiting episodes per day, the amount of vomits, the degree and length of nausea, as well as the distress associated with the condition [12]

All women were asked to mark their signs in the questionnaire corresponding to the intensity and frequency of nausea and vomiting. Methods: acupressure: The patient was relaxed and rested arms directly in front of the body with the fingers pointing up and palms facing body with relaxed shoulders. Nei Guan ( $\left.\mathrm{P}_{6}\right)$ pressure point was located on patient's arm by placing 3 fingers below the crease of the wrist and center the right thumb below them in between the two large tendons of Palmaris longus and the flexor carpi radials $[13,14]$.

Using either thumb, index or middle finger to press firmly on the Acupoint when women felt nauseous for 10 minutes and repeat the process for the other wrist with a total treatment period about 60 minutes of acupressure per day for 7 consecutive days. While the control group received only $\mathrm{P} 6$ touch with the same steps and period. Both groups were asked to point a degree on the Rhodes index scale according to severity and frequency of nausea and vomiting they felt, before and after intervention when she felt nauseated and vomits all over the seven days of acupressure intervention.

\section{Statistical analysis:}

The collected data were organized, categorized, tabulated and statistically analyzed using SPSS program version, data were presented in the tables using descriptive statistics in the form of frequencies, Chi-square test, percentage and mean score, standard deviation, comparison of means was performed using a paired $t$-test. Correlation among variables was done using person correlation coefficient. Significance was accepted at $p<0.05$ for interpretation of results of tests of significance.

\section{Results}

Table (1) shows Socio-demographic data of the studied groups. The mean age of the study group was $(20.84 \pm 1.68)$. While the mean age of the control group was $(21.44 \pm 2.06)$. About, $56 \%$ of the study group had secondary school while, $58 \%$ of the control group had university education and the remaining percentage in both groups varied in to read and write, post graduate, etc. Regarding occupation, more than $30 \%$ of the study and the control group were workers. All women in both groups were married with a non-significant difference between both groups in socio demographic characteristics ( $p$-value $>0.05$ ) which denotes homogeneity of the groups.

Table (2) shows family history of the studied groups. The majority of the study and the control group had the family history of medical diseases with about $41 \%$ in the study group and $61.5 \%$ in the control group suffered from hypertension and the remaining percentage had DM and others, without any significant difference between both groups ( $p$-value $>0.05$ ). 
Table (3) shows obstetric history of the studied groups. The mean of the current pregnancy duration per week were $(8.56 \pm 2.32$ weeks) in the study group and (9.18 \pm 1.72 weeks) in the control group. The majority of both groups had no complications during pregnancy. Nine women in the study group had gestational hypertension and only one woman had gestational DM. While, in the control group only five women had gestational hypertension with a non-significant difference between both groups ( $p$-value >0.05).

Table (4) shows gastric problems during pregnancy of the studied groups. Nearly all women in both groups suffered from nausea and vomiting during pregnancy. About $68 \%$ of women in the study group and $74 \%$ in the control group suffered from nausea and vomiting during the first month of pregnancy and the remaining percentage in the both groups felt NVP in second and third month of pregnancy. About $66 \%$ of the study group felt NVP discomfort twice a day, more than $20 \%$ of both groups reported discomfort once/day in addition to $14 \%$ and $8 \%$ felt discomfort 3 times per day for study and control group respectively. In addition, more than half of the women in both groups reported discomfort during eating. But, about $62 \%$ of the cases had moderate level of discomfort and the remaining percentage varied from mild and severe level of discomfort. Moreover, in the study group, about $72 \%$ of women had gastric problems due to full stomach but in the control group, $62 \%$ of women had the same problem. But, as regard to the number of meals taken during the day, in the study group, about $62 \%$ of cases had one to two meals during the day and $38 \%$ had from two to three meals. While, in control group, $50 \%$ of women had from one to two meals and the second half had two to three meals. Nausea and vomiting were increased with special foods in nearly all women of both study and control groups with no significant difference between both groups ( $p$-value >0.05).

The results of our study showed a highly significant decrease in the frequency of nausea and vomiting according to Rhodes index after 7 days in the study group than the control group ( $p$-value $\leq 0.001$ ) (Fig. 1).

While, comparing results of both groups during 7 days of the study showed a statistically significant difference of severity of nausea and vomiting during pregnancy ( $p$-value $\leq 0.001)$, Fig. (2). This difference indicated that acupressure has a positive effect on the reduction of severity of nausea and vomiting during pregnancy.
Table (1): Socio-demographic characteristics of the studied groups.

\begin{tabular}{|c|c|c|c|c|c|c|}
\hline \multirow{3}{*}{$\begin{array}{l}\text { Socio- } \\
\text { demographic } \\
\text { characteristics }\end{array}$} & \multicolumn{4}{|c|}{ Studied groups } & \multirow{3}{*}{$x^{2}$} & \multirow{3}{*}{$\begin{array}{c}p- \\
\text { value }\end{array}$} \\
\hline & \multicolumn{2}{|c|}{$\begin{array}{l}\text { Study group } \\
\quad(\mathrm{n}=50)\end{array}$} & \multicolumn{2}{|c|}{$\begin{array}{l}\text { Control group } \\
\qquad(n=50)\end{array}$} & & \\
\hline & No. & $\%$ & No. & $\%$ & & \\
\hline \multicolumn{7}{|l|}{ Age (years): } \\
\hline Mean \pm SD & \multicolumn{2}{|c|}{$20.84 \pm 1.68$} & \multicolumn{2}{|c|}{$21.44 \pm 2.06$} & $t=$ & 0.11 \\
\hline Range & \multicolumn{2}{|c|}{$17-24$} & \multicolumn{2}{|c|}{$18-25$} & 1.59 & NS \\
\hline \multicolumn{7}{|l|}{ Education: } \\
\hline Read \& write & 3 & 6.0 & 1 & 2.0 & \multirow[t]{4}{*}{5.90} & 0.11 \\
\hline Secondary school & 28 & 56.0 & 20 & 40.0 & & NS \\
\hline University & 18 & 36.0 & 29 & 58.0 & & \\
\hline Postgraduate & 1 & 2.0 & 0 & 0.0 & & \\
\hline \multicolumn{7}{|l|}{ Occupation: } \\
\hline Housewife & 34 & 68.0 & 32 & 64.0 & \multirow[t]{2}{*}{0.17} & 0.67 \\
\hline Worker & 16 & 32.0 & 18 & 36.0 & & NS \\
\hline
\end{tabular}

Table (2): Family history of the studied groups.

\begin{tabular}{|c|c|c|c|c|c|c|}
\hline \multirow{3}{*}{ Variable } & \multicolumn{4}{|c|}{ Studied groups } & \multirow{3}{*}{$\chi^{2}$} & \multirow{3}{*}{$\begin{array}{c}p- \\
\text { value }\end{array}$} \\
\hline & \multicolumn{2}{|c|}{$\begin{array}{l}\text { Study group } \\
(n=50)\end{array}$} & \multicolumn{2}{|c|}{$\begin{array}{l}\text { Control group } \\
\qquad(\mathrm{n}=50)\end{array}$} & & \\
\hline & No. & $\%$ & No. & $\%$ & & \\
\hline \multicolumn{7}{|c|}{$\begin{array}{l}\text { The family history } \\
\text { of medical disease: }\end{array}$} \\
\hline Yes & 32 & 62.0 & 39 & 78.0 & 3.04 & 0.08 \\
\hline No & 19 & 38.0 & 11 & 22.0 & & NS \\
\hline \multicolumn{7}{|c|}{$\begin{array}{l}\text { The family history } \\
\text { of medical disease: }\end{array}$} \\
\hline Hypertension & 13 & 41.9 & 24 & 61.5 & 2.77 & 0.25 \\
\hline DM & 11 & 35.5 & 10 & 25.6 & & NS \\
\hline Others & 7 & 22.6 & 5 & 12.8 & & \\
\hline
\end{tabular}

Table (3): Obstetric history of the studied groups.

\begin{tabular}{|c|c|c|c|c|c|c|}
\hline \multirow{3}{*}{ Obstetric history } & \multicolumn{4}{|c|}{ Studied groups } & \multirow{3}{*}{$x^{2}$} & \multirow{3}{*}{$\begin{array}{c}p- \\
\text { value }\end{array}$} \\
\hline & \multicolumn{2}{|c|}{$\begin{array}{l}\text { Study group } \\
\quad(\mathrm{n}=50)\end{array}$} & \multicolumn{2}{|c|}{$\begin{array}{l}\text { Control group } \\
(n=50)\end{array}$} & & \\
\hline & No. & $\%$ & No. & $\%$ & & \\
\hline $\begin{array}{l}\text { Duration of curren } \\
\text { pregnancy (weeks). } \\
\text { - Mean } \pm \text { SD } \\
\text { - Range }\end{array}$ & $\begin{array}{l}8.56 \\
1-12\end{array}$ & $=2.32$ & $\begin{array}{l}9 . \\
1-\end{array}$ & $=1.72$ & $\begin{array}{l}t= \\
1.51\end{array}$ & $\begin{array}{l}0.13 \\
\text { NS }\end{array}$ \\
\hline $\begin{array}{l}\text { Do complications } \\
\text { occur during } \\
\text { pregnancy: } \\
\text { - Yes } \\
\text { - No }\end{array}$ & $\begin{array}{l}11 \\
39\end{array}$ & $\begin{array}{l}22.0 \\
78.0\end{array}$ & $\begin{array}{l}5 \\
45\end{array}$ & $\begin{array}{l}10.0 \\
90.0\end{array}$ & 2.67 & $\begin{array}{l}0.10 \\
\text { NS }\end{array}$ \\
\hline $\begin{array}{l}\text { Complications } \\
\text { occur during } \\
\text { pregnancy: } \\
\text { - Gestational } \\
\text { hypertension } \\
\text { - Gestational DM } \\
\text { - Others }\end{array}$ & $\begin{array}{l}1 \\
1\end{array}$ & $\begin{array}{l}81.8 \\
9.1 \\
9.1\end{array}$ & $\begin{array}{l}0 \\
0\end{array}$ & $\begin{array}{l}100.0 \\
0.0 \\
0.0\end{array}$ & 1.03 & $\begin{array}{l}0.59 \\
\text { NS }\end{array}$ \\
\hline
\end{tabular}


Table (4): Gastric problems during pregnancy of the studied groups.

\begin{tabular}{|c|c|c|c|c|c|c|}
\hline \multirow{3}{*}{$\begin{array}{l}\text { Gastric problems } \\
\text { during } \\
\text { pregnancy }\end{array}$} & \multicolumn{4}{|c|}{ Studied groups } & \multirow{3}{*}{$x^{2}$} & \multirow{3}{*}{$\begin{array}{c}p- \\
\text { value }\end{array}$} \\
\hline & \multicolumn{4}{|c|}{$\begin{array}{l}\text { Study group Control group } \\
\qquad(\mathrm{n}=50)\end{array}$} & & \\
\hline & No. & $\%$ & No. & $\%$ & & \\
\hline \multicolumn{7}{|l|}{$\begin{array}{l}\text { Gastric problems } \\
\text { during pregnancy: }\end{array}$} \\
\hline - Nausea & 2 & 4.0 & 3 & 6.0 & $0.21 *$ & 1.0 \\
\hline $\begin{array}{c}\text { - Nausea \& } \\
\text { vomiting }\end{array}$ & 48 & 96.0 & 47 & 94.0 & & NS \\
\hline \multicolumn{7}{|l|}{$\begin{array}{l}\text { When did you feel } \\
\text { nausea and } \\
\text { vomiting? }\end{array}$} \\
\hline $\begin{array}{l}\text { - The first month of } \\
\text { pregnancy }\end{array}$ & 34 & 68.0 & 37 & 74.0 & 0.61 & $\begin{array}{l}0.73 \\
\text { NS }\end{array}$ \\
\hline $\begin{array}{l}\text { - The second month } \\
\text { of pregnancy }\end{array}$ & 14 & 28.0 & 12 & 24.0 & & \\
\hline $\begin{array}{l}\text { The third month } \\
\text { of pregnancy }\end{array}$ & 2 & 4.0 & 1 & 2.0 & & \\
\hline \multicolumn{7}{|l|}{$\begin{array}{l}\text { How many times do } \\
\text { you feel nausea and } \\
\text { vomiting? }\end{array}$} \\
\hline - One time/day & 10 & 20.0 & 14 & 28.0 & 1.50 & 0.47 \\
\hline - Two times/day & 33 & 66.0 & 32 & 64.0 & & NS \\
\hline - Three times/day & 7 & 14.0 & 4 & 8.0 & & \\
\hline \multicolumn{7}{|l|}{$\begin{array}{l}\text { When do you feel } \\
\text { nausea and } \\
\text { vomiting? }\end{array}$} \\
\hline - In the morning & 4 & 8.0 & 3 & 6.0 & 4.49 & 0.10 \\
\hline - During eating & 27 & 54.0 & 37 & 74.0 & & NS \\
\hline - After eating & 19 & 38.0 & 10 & 20.0 & & \\
\hline \multicolumn{7}{|l|}{$\begin{array}{l}\text { Grading level of } \\
\text { distress from } \\
\text { nausea and } \\
\text { vomiting: }\end{array}$} \\
\hline - Mild & 1 & 2.0 & 3 & 6.0 & 1.11 & 0.57 \\
\hline - Moderate & 31 & 62.0 & 31 & 62.0 & & NS \\
\hline - Severe & 18 & 36.0 & 16 & 32.0 & & \\
\hline \multicolumn{7}{|l|}{$\begin{array}{l}\text { Are nausea and } \\
\text { vomiting related to } \\
\text { full stomach? }\end{array}$} \\
\hline - Yes & 36 & 72.0 & 31 & 62.0 & 1.24 & 0.53 \\
\hline$\cdot$ No & 1 & 2.0 & 2 & 4.0 & & NS \\
\hline - Sometimes & 13 & 26.0 & 17 & 34.0 & & \\
\hline \multicolumn{7}{|l|}{$\begin{array}{l}\text { How many meals } \\
\text { taken during the } \\
\text { day? }\end{array}$} \\
\hline - $1-2$ & 19 & 38.0 & 25 & 50.0 & 1.46 & 0.22 \\
\hline$\cdot 2-3$ & 31 & 62.0 & 25 & 50.0 & & NS \\
\hline \multicolumn{7}{|l|}{$\begin{array}{l}\text { Do nausea and } \\
\text { vomiting increases } \\
\text { with special foods? }\end{array}$} \\
\hline - Yes & 45 & 90.0 & 48 & 96.0 & $1.38^{*}$ & 0.43 \\
\hline - No & 5 & 10.0 & 2 & 4.0 & & NS \\
\hline
\end{tabular}

*: Fisher's exact test.

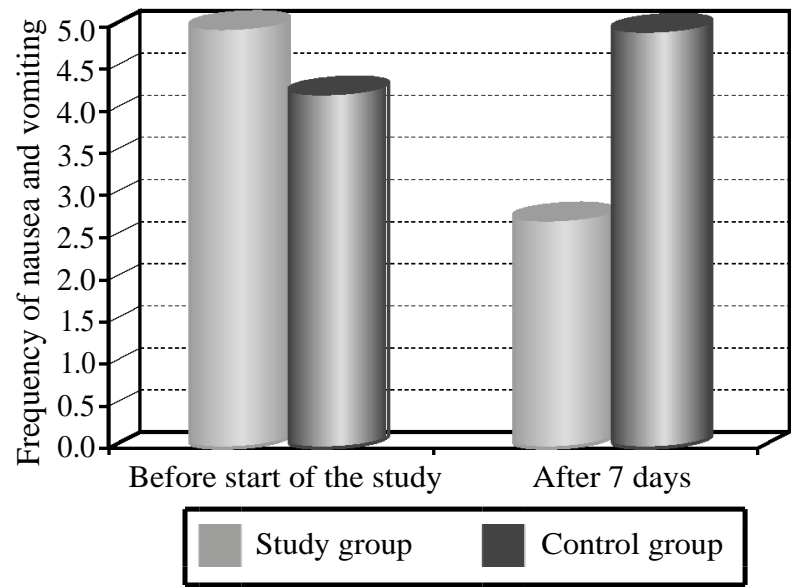

Fig. (1): Frequency of nausea and vomiting of both groups before the start of the study and after 7 days according to Rhodes index.

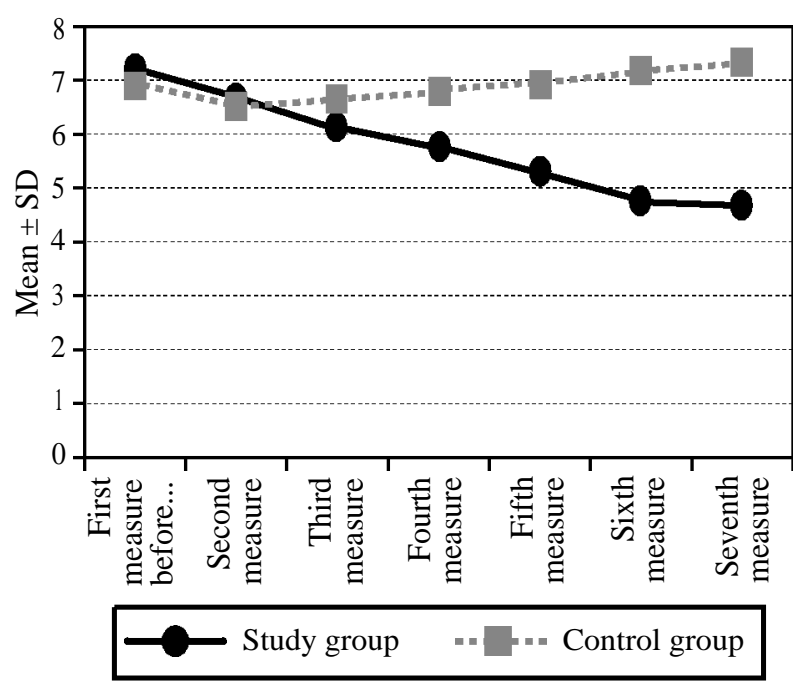

Fig. (2): Severity of nausea and vomiting as assessed by Rhodes index scale of the studied groups before starting the study and at the end of seven days.

\section{Discussion}

The main objective of this study was to evaluate the effects of acupressure on nausea and vomiting as perceived by pregnant women when acupressure was applied to the P6 Acupoint.

The results of the present study revealed no significant statistical difference in the basic data between the study and control groups as regard to age, education, occupation, and marital status that indicating homogeneity of the sample. But, regarding the frequency of nausea and vomiting, the results of this study revealed a significant decrease in frequency of nausea and vomiting in the study group after 7 days of treatment as compared to control group.

This finding is consistent with Helmreich et al. [15], Dundee et al., [16], Jamigorn \& Phupong [17], 
Nunley et al., [18], Aghamiri et al., [19], Brien et al., [20], Lee et al., [14], Norheim et al., [21] and Saberi et al., [22] and Mansour et al., [23] who stated in their studies that $\mathrm{P} 6$ acupressure was effective in decreasing frequency of nausea, vomiting and retching episodes in women with hyperemesis gravidarum.

In addition, Saberi et al., [22] in Iran, used the same gestational age and the same Acupoint as the same study, examined the effect of acupressure and Ginger in relieving NVP in pregnant women in less than 16 weeks of gestational age and showed that both acupressure and Ginger were effective in decreasing frequency and severity of nausea and vomiting.

But, Chernyak and Sessler [24] reported in the systematic review examined the effects of acupressure and acupuncture in treating nausea or vomiting in early pregnancy with the sample size nearly equal to the present study sample. The result found limited evidence that acupressure reduced the proportion of women reporting morning sickness compared with sham acupressure.

Moreover, regarding the severity of nausea and vomiting of pregnancy, the present study revealed a highly significant difference in severity of nausea and vomiting before the study and after acupressure in comparing data of both groups, indicating that acupressure has a positive effect on the reduction of severity of nausea and vomiting.

Markose et al., [25] in Iran who used the same P6 acupoint and reported that acupressure reduced the severity of nausea and vomiting significantly in the study group compared to the control group.

In contrast, Wood et al., [26] mentioned that acupressure was ineffective in reducing nausea and vomiting of pregnancy in studying the effect of acupressure on $\mathrm{P} 6$ Acupoint on nausea and vomiting of early pregnancy. Also, Dibble et al., [27] concluded that there is a lack of high-quality evidence to support advice on acupressure for nausea and vomiting in pregnancy.

This finding is in agreement with Philip [28] and Matthews et al., [4] who stated that nonpharmacologic therapy such as acupressure was equal to commonly used antiemetic drugs.

This can be explained by the Nunley et al., [29] who reported that $\mathrm{P} 6$ acupressure is effective in relieving nausea and vomiting as it stimulates blood circulation and then inhibits the activities of the cerebral cortex through neural stimulation.
Also, in traditional Chinese medicine, $\mathrm{P} 6$ or Neiguan point acupressure brings the balance of energy life force or Chi to the pericardial meridian. The pericardial meridian controls the functions of the heart and respiration. Neiguan points located at the right wrist are where the negative energy from the heart leaves the body, and Neiguan points at the left wrist are where the positive energy enters from the outside to inside the body. When there is a balance between Yin and Yang, nausea will be controlled [16].

In general, it was found that acupressure on Neiguan point $(\mathrm{P} 6)$ is an appropriate method and can be considered a good alternative method in treating nausea and vomiting in pregnant women without any side effects like medical treatment.

\section{Conclusions:}

The present study concluded that acupressure on Neiguan point ( $\mathrm{P} 6)$ is effective in reducing the severity and frequency of nausea and vomiting in pregnant women. This is consistent with the advantages of Acupressure as a simple, non-invasive technique without side effects on the pregnant woman and her fetus.

\section{Recommendations:}

The results of this study proposed the suggestion of the following recommendations:

- Encourage the use of P 6 acupressure as an alternative method in the treatment of nausea and vomiting of pregnancy that can reduce the risks of anti-nausea drugs during the first trimester.

- It is recommended that acupressure can be taught to maternity care personnel as refreshment courses and be presented to patients complaining from nausea and vomiting in the form of pamphlets and health magazines.

\section{- Further studies are needed for:}

- Assessing the effect of acupressure to other Acupoints on the treatment of nausea and vomiting of pregnancy and comparing the effect of different Acupoints in reducing nausea and vomiting of pregnancy.

- Using a larger sample size and objective data such as body weight change, urine ketone, and blood electrolyte to support the efficacy of acupressure in cases of nausea and vomiting of pregnancy.

\section{References}

1- SMITH C., CROWTHER C., BEILBY J. and DANDEAUX J.: The impact of nausea and vomiting on women: 
A burden of early pregnancy. Aust. N. Z. J. Obstet. Gynecol., 4: 397-401, 2000.

2- MILLER F.: Nausea and vomiting in pregnancy: The problem of perception--is it really a disease? American Journal of Obstetrics and Gynecology, 186 (5 Suppl): S182-S183, 2002.

3- WOOLHOUSE M.: Complementary medicine for pregnancy complications. Australian Family Physician, 35 (9): 695, 2007.

4- MATTHEWS A., DOWSWELL T., HAAS D., DOYLE M. and O'MATHÚNA D.: Interventions for nausea and vomiting in early pregnancy. Cochrane Database System Rev., 9: CD007575, 2010.

5- SHERMAN P. and FLAXMAN S.: Nausea and vomiting of pregnancy in an evolutionary perspective. Am. J. Obstet. Gynecol., 190-7, 2002.

6- MAHMOUD G.: Prevalence and Risk Factors of Hyperemesis Graviderum Among Egyptian Pregnant Woman at the Woman's Health Center Med. J. Cairo Univ., 80 (2): 161-8, 2012.

7- WILLS G. and FORSTER D.: Nausea and vomiting in pregnancy: What advice do midwives give? Midwifery, 24 (4): 390-8, 2008.

8- WERNTOFT E. and DYKES A.: Effect of acupressure on nausea and vomiting during pregnancy. A randomized, placebo-controlled, pilot study. J. Reprod Med., 46 (9): 835-9, 2001.

9- MELTZER D.: Complementary Therapies for nausea and vomiting in early pregnancy. Family Practice, 17: 5703, 2000 .

10- CASTILLO M. and PHILLIPPI J.: Hyperemesis Gravidarum; A Holistic Overview and Approach to Clinical Assessment and Management. The Journal of Perinatal \& Neonatal Nursing, 29 (1): 12-22, 2015.

11-SMITH C., COLLINS C., CROWTHER C. and LEVETT K.: Acupuncture or acupressure for pain management in labor. Cochrane Database Syst. Rev., (7): CD009232, 2011.

12- KIM T., CHOI B., CHIN J., LEE M., KIM D. and NOH G.: The Reliability and Validity of the Rhodes Index of Nausea, Vomiting and Retching in Postoperative Nausea and Vomiting. Korean J. Anesthesiol., 52 (6): S 59-65, 2007.

13- PUANGSRICHARERN A. and MAHASUKHON S.: Effectiveness of auricular acupressure in the treatment of nausea and vomiting in early pregnancy. J. Med. Assoc. Thai., 91 (11): 1633-8, 2008.

14- LEE E. and FRAZIER S.: The efficacy of acupressure for symptom management: A systematic review. J. Pain Symptom Manage, 42 (4): 589-603, 2011.

15-HELMREICH R., SHIAO S. and DUNE L.: Meta-analysis of acustimulation effects on nausea and vomiting in pregnant women. Explore (NY), 2: 412-21, 2006.
16- DUNDEE J., YANG J. and McMILLAN C.: Non-invasive stimulation of the P6 (Neiguan) antiemetic acupuncture point in cancer chemotherapy. Journal of Royal Society of Medicine, 84: 210-2, 2007.

17- JAMIGORN M. and PHUPONG V.: Acupressure and vitamin B 6 to relieve nausea and vomiting in pregnancy: A randomized study Arch. Gynecol. Obstet., 276: 2459, 2007.

18- NUNLEY C., WAKIM J. and GUINN C.J.: The effects of stimulation of acupressure point $\mathrm{P} 6$ on post-operative nausea and vomiting: A review of literature Perianesth Nurs. Aug., 23 (4): 247-61, 2008.

19- AGHAMIRI Z., HOSEINI N., RAMEZANZADEH F. HAGHOLLAHI F. and VIJEH M.: Effects of acupressure on frequency and severity of the nausea of pregnancy. Payesh Health monitor. Payesh Health Monit., 7 (4): 36974, 2008.

20- BRIEN B., RELYEA M. and TAERTUM T.: Efficacy of P6 acupressure in the treatment of nausea and vomiting during pregnancy. American Journal of Obstetrics and Gynecology, 174 (2): 708-15, 2010.

21- NORHEIM A., PEDERSEN E., FONNEBO V. and BERGE L.: Acupressure treatment of morning sickness in pregnancy. Scand. J. Prim. Health Care, 19: 43-7, 2001.

22- SABERI F., SADAT Z., ABEDZADEH-KALAHROUDI M. and TAEBI M.: Acupressure and Ginger to Relieve Nausea and Vomiting in Pregnancy. Iranian Red Crescent Medical Journal. September, 15 (9): 854-61, 2013.

23- MANSOUR S., EMAM M., ELGHORY A. and SHEBL A.: Effect of Nurses Using for P 6 Acupressure on Nausea, Vomiting, and Retching in Women with Hyperemesis Gravidarum, IOSR-JNHS, 4 (4): 01-09, 2015.

24- CHERNYAK G. and SESSLER C.: Perioperative acupuncture and related techniques. Anesthesiology, 102: 1031-49, 2005.

25- MARKOSE M., RAMANATHAN K. and VIJAYAKUMAR J.: Reduction of nausea, vomiting, and dry retches with $\mathrm{P} 6$ acupressure during pregnancy. International Journal of Gynecology \& Obstetrics, 85: 168-9, 2004.

26- WOOD H., McKELLAR L. and LIGHTBODY M.: Nausea and vomiting in pregnancy: Blooming or bloomin' awful? A review of the literature. Women Birth, 26 (2): 100-4, 2015.

27- DIBBLE S., CHAMPMAN J., MACK K. and SHIH A.: Acupressure for nausea: Results of a pilot study. Oncol. Nurs. Forum., 27: 41-6, 2010.

28- PHILIP B.: Hyperemesis gravidarum literature review. Wisconsin Medical Journal, 102 (3): 46-51, 2003.

29- NUNLEY C., WAKIM J. and GUINN C.: The Effects of Stimulation of Acupressure Point P 6 on Postoperative Nausea andVomiting: A Review of Literature. Journal of Peri Anesthesia Nursing, 23 (4): 247-61, 2008. 


\section{تآثير الضغط الهوضعى على الغثيان والقئ آثناء الحمل}

المقدمة: الضغط الموضعى هو جزء من الطب الصينى التقليىى لتحفيز قنوات الطاقة تحت سطع الجلد، لآنه يقل من الإجهاد ويعيد الصحة. الهدف من هذه الدراسة: دراسة تآثير الضغط الموضعى فى علاج الإحساس بالغثيان والقئ آثناء الحمل.

طريقة وآدوات البحث: تم تضمين . إ إمرآة حامل فى عمر الحمل آقل من ها إسبوعا فى دراسة لمدة V آيام متتالية. تم تقسيمهم

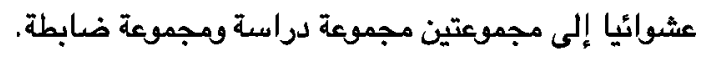

تلقت مجموعة الدراسة الضغط الموضعى على نقطة الضغط (P6) على الجانبين لمدة .7 دقيقة يوميا لمدة V آيام متتالية، بينما تلقت

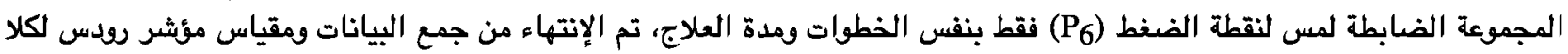
المجموعتين.

وآسفرت النتائج عن إنخفاض شدة وتكرار حلوث الغثيان والقئ بثكل ملحوظ فى مجموعة الدراسة بعد بدء العلاج مقارنة بالمجموعة الضابطة. الإستتاجات: يعد الضغط الموضعى علاجا فعالا للصد من شدة وتكرار حدوث الغثيان والقئ آثناء الحمل. 